\title{
Pembuatan Sediaan Tabir Surya Ekstrak Etanol Rimpang Temu Kunci (Boesenbergia pandurata (Roxb.) Schlecht), Aktivitas Inhibisi Fotodegradasi Tirosin dan Kandungan Fenolik Totalnya
}

\author{
Formulation of Temu Kunci (Boesenbergia pandurata (Roxb.) Schlecht) Rhizome Extract \\ Sunscreen, Inhibition Activity of Tyrosine Photodegradation and Its Total Phenolic Compounds
}

\author{
Tatang Irianti ${ }^{*}$, Teuku Nanda Saifullah Sulaiman ${ }^{1}$, Nanang Fakhrudin ${ }^{1}$, Siluh Astuti ${ }^{2}$, Nita \\ Testikawati $^{2}$, Soda Farida ${ }^{2}$, Jovanita Fara Addina ${ }^{2}$ \\ 1 Fakultas Farmasi, Universitas Gadjah Mada \\ 2 Balai Besar Penelitian dan Pengembangan Tanaman Obat Tradisional, Badan Penelitian dan \\ Pengembangan Kesehatan
}

Corresponding author: Tatang Irianti: Email: intanti@ugm.ac.id

Submitted: 03-03-2020 Revised: 19-03-2020 Accepted: 16-06-2020

\begin{abstract}
ABSTRAK
Indonesia merupakan negara tropis dengan intensitas sinar matahari yang tinggi sehingga hal ini dapat memberikan dampak negatif terhadap kulit manusia. Untuk mencegah kerusakan akibat dari cahaya matahari diperlukan suatu bahan yang bersifat fotoprotektor dengan mekanisme kerja menyerap atau menghalangi cahaya matahari masuk ke kulit. Flavonoid ekstrak etanol rimpang temu kunci (Boesenbergia pandurata (Roxb.) Schlecht) diketahui memiliki aktivitas sebagai fotoprotektor. Penelitian ini bertujuan untuk mengetahui pengaruh ekstrak etanol rimpang temu kunci dalam sediaan tabir surya yang mengandung bahan aktif oksibenson sebagai fotoprotektor; mengetahui aktivitas fotodegradasi tirosin serta kadar fenolik total ekstrak etanol rimpang temu kunci. Pada penelitian ini dilakukan dengan menguji delapan formula. Penentuan kemampuan fotoproteksi berdasarkan nilai transmisi eritema dan transmisi pigmentasi. Uji inhibisi fotodegradasi dilakukan dengan menggunakan enam kelompok komposisi tirosin dan Rhetoflam. Uji penentuan kadar fenolik total dilakukan menggunakan metode Follin-Ciocalteu. Hasil pengukuran diintrapolasikan ke dalam kurva baku asam galat. Penambahan ekstrak etanol rimpang temu kunci mampu menurunkan transmisi eritema 0,72-0,76 kali dan transmisi pigmentasi 0,57-0,61 kali dari sediaan tabir surya. Pemberian ekstrak etanol rimpang temu kunci $6 \%$ pada sediaan tabirsurya mengandung oksibenson 6\% meningkatkan efektivitas tabir surya dengan menurunkan transmisi eritema 1,00 kali dan transmisi pigmentasi 1,02 kali lebih baik dari sediaan tabir surya mengandung bahan aktif oksibenson saja. Sedangkan kandungan fenolik total ekstrak etanol ripang temu kunci adalah sebesar 7,11 $\pm 0,15 \%$ EAG dengan aktivitas penghambatan fotodegradasi tirosin 2,06 kali lebih besar dibandingkan dengan vitamin $C$ pada kadar yang sama, yaitu $0,15 \%$. Hal ini menunjukkan bahwa ekstrak etanolik rimpang temu kunci dapat dimanfaatkan sebagai bahan aktif fotoprotektor dalam sediaan kosmetik.
\end{abstract}

Kata kunci: Temu Kunci; Fotoproteksi; Fotodegradasi; Tabir Surya

\section{ABSTRACT}

Indonesia is a tropical country with high intensity of sunlight that can give negative impact on human skin. Photoprotector material which absorb or block sunlight from entering the skin is important to prevent damage due to sunlight. Ethanolic extract of temu kunci (Boesenbergia pandurata (Roxb.) Schlecht) rhizome contains flavonoid which known to have activity as photoprotectors. This study aims to determine ethanolic extract of temu kunci rhizome's effect in sunscreen preparations containing oxybenson active ingredient as photoprotector; knowing the tyrosine photodegradation activity and its total phenolic content. This research was conducted by testing eight formulas. Determination of photoprotection ability based on the value of erythema transmission and pigmentation transmission. The photodegradation inhibition assay was carried out using six groups of tyrosine and Rhetoflam compositions. The total phenolic concentration determination was carried out using the Folin-Ciocalteu method. The measurement results are interpolated into the raw curve of gallic acid. The addition of ethanolic extract of temu kunci rhizomes 
was able to reduce erythema transmission from 0.72 to 0.76 times and decrease in pigmentation transmission 0.57-0.61 times from sunscreen preparations. The amount of $6 \%$ temu kunci rhizome extract was not affected whether by reducing the transmission of erythema or decreasing the transmission of pigmentation. Whereas the total phenolic content of temu kunci rhizome ethanolic extract was $7.11 \pm 0.15 \%$ EAG with the inhibitory activity of tyrosine photodegradation 2.06 times greater than vitamin $C$ at the same level, which was $0.15 \%$. This shows that temu kunci rhizome ethanolic extract can be used as an active ingredient of photoprotector in cosmetic preparations.

Keywords: Temu Kunci; Photoprotection; Photodegradation; Sun Protection

\section{PENDAHULUAN}

Indonesia merupakan salah satu daerah tropis dan mempunyai paparan sinar matahari dengan intensitas tinggi. Sinar uv yang mengenai kulit secara terus menerus dapat menyebabkan perubahan struktur dan komposisi hingga menimbulkan stress oksidatif pada kulit (Droge, 2002; Kockler et al., 2012). Hal tersebut dapat diamati dari perubahanperubahan jangka pendek namun bersifat akut seperti pigmentasi, eritema, fotosensitifitas, bahkan efek jangka panjang seperti penuaan dini dan keganasan atau kanker kulit (Tahir dkk., 2002). Peningkatan kerusakan lingkungan juga dapat memproduksi agen-agen oksidatif sehingga memproduksi radikal bebas.

Antioksidan dapat mengurangi reaksi oksidasi yang dipicu oleh berbagai agen oksidatif walaupun secara topikal untuk mencegah kerusakan akibat radikal bebas. Aktivitas antioksidan dapat ditemukan dalam tumbuhan sebagai senyawa fenolik (Svobodova et al., 2003). Senyawa fenlolik dapat digunakan untuk melindungi jaringan tubuh dari kerusakan akibat paparan sinar matahari dalam kaitannya sebagai fotoprotektor (Halliwel, B. \& Gutteridge, 1999). Beberapa antioksidan terpenting seperti Vitamin E, Vitamin C, dan flavonoid banyak digunakan dalam kosmetik (Barel, 2001).

Menurut Raga (2012), senyawa flavonoid memiliki sifat antioksidan sebagai penangkap radikal bebas karena mengandung gugus hidroksil yang bersifat sebagai reduktor dan dapat bertindak sebagai donor hidrogen terhadap radikal bebas.

Temu kunci (Boesenbergia pandurate (Roxb.) Schlecht) memiliki kandungan senyawa dengan aktivitas antioksidan dari golongan flavonoid terutama pinostrobin dan pinoscembrin (Shindo dkk., 2006 dan Tewtrakul dkk., 2003). Senyawa fenolik berupa flavonoid dapat berperan sebagai tabir surya untuk mencegah efek merugikan akibat radiasi UV pada kulit karena adanya antioksidan sebagai fotoprotektor (Svobodova et al., 2003). Suryanto (2012) dan Sartini (2007) juga mengatakan bahwa senyawa flavonoid, katekin, epikatekin, dan tannin memiliki aktivitas antioksidan yang berpotensi sebagai tabir surya, penyegar kulit, dan pengatur keseimbangan radikal bebas untuk memperlambat proses penuaan. Salah satu sediaan kosmetika yang banyak dijumpai seperti tabir surya sangat penting, karena dapat mengurangi efek buruk dari sinar matahari dengan kemampuan dapat menyaring sinar matahari (sunscreen) atau bahkan menahan seluruh sinar matahari (sunblock).

Proses sintesis melanin menyebabkan terjadinya pigentasi pada kulit, hal ini dicipu oleh adanya sinar matahari karena melanin merupakan agen perlindungan tubuh alami terhadap paparan sinar matahari. Melanin terbentuk dari asam amino tirosin dengan bantuan enzim tirosinase. Pigmen melanin dianggap sebagai turunan dari tirosin, dimana melanin merupakan asam amino yang digunakan sel untuk sintesis protein. Sediaan kosmetik seperti tabir surya dengan kombinasi oksibenson dapat berperan baik sebagai anti-UV A. Pada cakupan panjang gelombang 320-360 nm, oksibenson dapat digunakan sebagai proteksi dengan menyerap UV A dan 2-6\% b/b merupakan konsentrasi umum oksibenson yang biasa digunakan (Shaath, 1990). Kemampuan temu kunci sebagai agen penyerap UV dan penangkal radikal bebas dapat diproyeksikan dalam perhitungan besarnya aktivitas inhibisi (penghambatan) forodegradasi dari tirosin dibandingkan dengan Vitamin C.

Hal ini memunculkan suatu pemikiran untuk menambahkan suatu bahan tambahan alami untuk dapat mengoptimalkan fungsi dari sediaan tabir surya. Maka dari itu, hal ini mendasari dilakukannya penelitian untuk menguji pengaruh penambahan ekstrak etanolik rimpang temu kunci (Boesenbergia pandurate (Roxb.) Schlecht) terhadap efektivitas sediaan tabir surya sebagai bahan proteksi 
terhadap sinar UV, meliputi nilai \% transmisi eritema (\%Te) dan \% transmisi pigmentasi (\%Tp). Penentuan kadar fenolik total dan aktivitas inhibisi fotodegradasi tirosin diharapkan memberikan nilai yang baik dalam kaitannya sebagai fotoprotektor.

\section{METODOLOGI Bahan}

Bahan yang digunakan dalam penelitian ini adalah: rimpang temu kunci (Boesenbergia pandurata (Roxb.) Schlecht) (Samigaluh, Kulon Progo), tirosin (Wako Pure), ketoprofen topikal merk (Rhetoflam)® 25 mg (Kimia Farma), Vitamin C (E. Merck), $\mathrm{HgSO}_{4}$ (E. Merck), $\mathrm{H}_{2} \mathrm{SO}_{4}$, (E. Merck), $\mathrm{NaNO}_{2}$ (E. Merck), $\mathrm{NaOH}$ (E. Merck), reagen Folin-Ciocalteau (E. Merck), $\mathrm{Na}_{2} \mathrm{CO}_{3}$, (E. Merck), aquadest, $\mathrm{C}_{2} \mathrm{H}_{5} \mathrm{OH}$ (E. Merck), oksibenson (atas jasa PT. Vitapharm), asam stearat (Brataco), setil alkohol (Brataco), span 60 (Brataco), tween 60 (Brataco), larutan sorbitol (Brataco), metil paraben (Brataco), dan propil paraben (Brataco), aquades (General Lab), isopropanol (p.a. E.Merck) dan etanol (p.a. E.Merck), etanol 70\% (teknis, General Lab), lempeng KLT siliks gel $\mathrm{G} \mathrm{F}_{254}$ (E.Merck), dan rutin trihydrate (Fluka Biochemika).

\section{Alat}

Alat yang digunakan dalam penelitian ini adalah cawan porselen, kertas $\mathrm{pH}$, alat uji daya lekat, alat uji daya sebar, viscotester (Rion VT04), sentrifuge (Hettich), spektrofotometer (Hitachi U-2800), neraca analitik (Ohoaus), waterbath (memmert), stopwatch, panci infusa, lampu merkuri (Sankyo Denki 20 watt), mikropipet (Trasferpette $®)$, vortex (Maxi Mix Plus TM), spektrofotometer (Genesys10), kompor listrik (Robusta $\AA$ ), yellow tip, blue tip, dan seperangkat alat gelas.

\section{Jalannya Penelitian}

Determinasi Tanaman

Determinasi tanaman dilakukan di Laboratorium Biologi Farmasi Universitas Gadjah Mada berdasarkan persamaan ciri-ciri morfologi tanaman dengan ciri-ciri tanaman dalam pustaka buku Flora of Java (Backer and Van Den Brink, 1965).

Ekstraksi Rimpang Temu Kunci

Simplisisa rimpang temu kunci terlebih dahulu dicuci dengan air mengalir untuk menghilangkan sisa-sisa kotoran yang menempel pada bagian rimpang temu kunci, selanjutnya rimpang temu kunci dirajang dengan ketebalan $\pm 3 \mathrm{~mm}$. Setelah rimpang dirajang kemudian dikeringkan di dalam oven dengan suhu $50^{\circ} \mathrm{C}$ selama 24 jam untuk selanjutnya diserbuk.

\section{Penetapan Kadar Fenolik Total}

Metode Folin-Ciocalteu dipilih untuk penetapan kadar fenolik total ekstrak etanol rimpang temu kunci. Konsentrasi larutan induk (Li) asam galat sebesar 1 $\mathrm{mg} / \mathrm{ml}$ dalam etanol digunakan untuk membuat kurva. Sebanyak 10; 20; 30; 40; 50; 60; dan $70 \mu \mathrm{l}$ Li dimasukkan dalam labu takar $10 \mathrm{ml}$, ditambah dengan 0,4 ml reagen Folin-Ciocalteu, dan dibiarkan selama 5-8 menit. Selanjutnya ditambahkan sebanyak $4 \mathrm{ml} \mathrm{Na}_{2} \mathrm{CO}_{3} 7 \%$ dan aquadest sampai tanda batas. Absorbansinya dibaca pada panjang gelombang $750 \mathrm{~nm}$ setelah 2 jam. Lalu dilakukan pembacaan blangko yang terdiri atas aqua bidestilata dan reagen Folin-Ciocalteu. Kemudian diambil $75 \mu$ l ekstrak etanol rimpang temu kunci $1 \%$ dan dilanjutkan sebagaimana perlakuan pada pembuatan kurva baku untuk penetapan kadar fenolik total. Pengukuran dilakukan replikasi sebanyak enam kali.

\section{Uji Pendahuluan}

\section{Pembuatan Formula}

Fase air terdiri dari ekstrak rimpang temu kunci, Tween 60, dan larutan sorbitol. Fase minyak terdiri dari setil alkohol, asam stearat dan Span 60. Kedua fase tersebut masingmasing dipanaskan di atas waterbath hingga suhu $80^{\circ} \mathrm{C}$. Selanjutnya fase air ditambahkan ke dalam fase minyak sambil di aduk. Campuran ini kemudian ditambahkan ke dalam campuran metil paraben dan propil paraben yang sebelumnya telah dilarutkan dalam air.

Ditambahkan sedikit demi sedikit air ke dalam campuran formula sampai formula mencapai $100 \%$ sambil terus di aduk hingga diperoleh masa krim yang diinginkan. Komposisi formula basis emulsai dapat dilihat pada Tabel I.

\section{Uji Mutu Fisik Pendahuluan \\ Uji mutu fisik pendahulan dilakukan} dengan mengamati penampilan fisik krim yang 
Tabel I. Formula Basis Emulsi menggunakan Surfaktan Nonionik menurut Lachman et al., (1994) dengan Beberapa Pengembangan

\begin{tabular}{lcccc}
\hline Komponen & F1(\%) & F2(\%) & F3(\%) & F4(\%) \\
\hline Asam stearate & 14 & 14 & 14 & 14 \\
Setil alcohol & 1 & 1 & 1 & 1 \\
Span 60 & 2 & 1,5 & 3,5 & 0 \\
Tween 60 & 1,5 & 2 & 0 & 3,5 \\
Larutan sorbitol 70\% & 3 & 3 & 3 & 3 \\
Metilparaben & 0,1 & 0,1 & 0,1 & 0,1 \\
Propilparaben & 0,05 & 0,05 & 0,05 & 0,05 \\
Aquadest & ad 100 & ad 100 & ad 100 & ad 100 \\
\hline
\end{tabular}

diperoleh yang meliputi warna, bau, tekstur, homogenitas, $\mathrm{pH}$, dan viskositas.

\section{Daya Sebar Basis}

Uji daya sebar dilakukan dengan meletakkan sebanyak 0,5 gram krim di tengah alat (kaca bulat). Kaca penutup ditimbang, kemudian diletakkan di atas

krim dan dibiarkan selama 1 menit. Penyebaran basis diukur diameternya dengan mengambil panjang rata-rata diameter dari beberapa sisi. Selanjutnya beban tambahan diletakkan di atas basis seberat 50 gram, didiamkan selama 1 menit dan dicatat diameter penyebaran basis. Percobaan diteruskan tiap kali dengan penambahan beban sebanyak 50 gram dan dicatat diameter penyebaran basis selama 1 menit.

Uji Daya Lekat Basis

Uji daya lekat dilakukan dengan meletakkan sejumlah krim diatas gelas objek yang telah ditentukan luasnya, gelas objek lain diletakkan diatas krim dan ditekan dengan memberikan beban $1 \mathrm{~kg}$ selama 5 menit. Selanjutnya dipasang gelas objek pada alat uji daya lekat kemudian dilepaskan beban 80 gram dan dicatat waktu yang dibutuhkan hingga kedua obyek glass tersebut terlepas.

Uji Volume Pemisahan dengan Sentrifugasi

Uji volume pemisahan dengan sentrifugasi dilakukan dengan memasukkan basis krim ke dalam tabung sentrifuge berskala sampai skala tertentu. Selanjutnya tabung berisi krim tersebut dimasukkan ke dalam sentrifuge dan diputar dengan kecepatan $1000 \mathrm{rpm}$. Volume pemisahan yang terjadi dicatat setiap selang waktu 5 menit sampai menit ke 15 . Percobaan tersebut diulangi dengan menggunakan kecepatan putaran $2000 \mathrm{rpm}$ dan $3000 \mathrm{rpm}$.

$$
\frac{\text { volume emulsi yang memisah }}{\text { volume emulsi keseluruhan }} \times 100 \%
$$

Uji Volume Pemisahan dengan Sedimentasi Basis dimasukkan ke dalam 2 tabung reaksi berskala sampai skala tertentu. Basis yang berada di tabung reaksi berskala disimpan masing-masing pada suhu $50^{\circ} \mathrm{C}$ dan suhu kamar. Tiap selang waktu 5 menit sampai menit ke-30, volume pemisahan basis pada suhu $50^{\circ} \mathrm{C}$ dicatat. Tiap dua hari sekali sampai hari ke-40, volume pemisahan basis pada suhu kamar dicatat. Volume pemisahan dapat dihitung dengan menggunakan rumus pada persamaan (1).

\section{Formulasi dan Analisis Sediaan Tabir Surya}

Formulasi Sediaan Tabir Surya

Sediaan krim tabir surya dibuat dengan menggunakan bahan basis terpilih dengan penambahan bahan aktif oksibenson dan ekstrak etanol rimpang temu kunci yang dibuat ke dalam 8 formula baru dengan komponen seperti tercantum pada Tabel II.

\section{Penetapan Mutu Fisik Sediaan}

Pengujian mutu fisik sediaan tabir surya meliputi uji organoleptis (bentuk, warna, bau, dan tekstur), $\mathrm{pH}$, dan viskositas.

Penetapan Persen Transmisi Eritema (\%Te) dan Transmisi Pigmentasi (\%Tp)

Penetapan nilai transmisi eritema dari sediaan tabir surya ditentukan secara spektrofotometri dengan menggunakan pelarut isopropanol pada rentang panjang gelombang 292,5-372,5 nm (Cumpelik, 1972). 
Tabel II. Formula Sediaan Tabir Surya

\begin{tabular}{cccc}
\hline Formula & Basis & Oksibenson & Ekstrak \\
\hline 1 & + & - & - \\
2 & + & $6 \%$ & - \\
3 & + & - & $4 \%$ \\
4 & + & - & $6 \%$ \\
5 & + & - & $8 \%$ \\
6 & + & $6 \%$ & $4 \%$ \\
7 & + & $6 \%$ & $6 \%$ \\
8 & + & $6 \%$ & $8 \%$ \\
\hline
\end{tabular}

Tabel III. Komposisi Bahan dalam Tiap Tabung Perlakuan pada Uji Pengaruh Lama Penyinaran terhadap Fotodegradasi Tirosin

\begin{tabular}{ccccc}
\hline Kelompok & \multicolumn{3}{c}{ Isi Bahan dalam Tabung } & Lama Penyinaran \\
\cline { 2 - 4 } Perlakuan & Tirosin 0,05\% (m) & Rhetoflam 1\% $(\boldsymbol{\mu l})$ & Aquadest (ml) & ad \\
\hline $\mathrm{P}_{0}$ & 2,0 & 600 & ad 5 & 0 \\
$\mathrm{~B}_{0}$ & - & 600 & ad 5 & 60 \\
$\mathrm{P}_{1}$ & 2,0 & 600 & ad 5 & \\
$\mathrm{B}_{1}$ & - & 600 & ad 5 & 120 \\
$\mathrm{P}_{2}$ & 2,0 & 600 & ad 5 & \\
$\mathrm{B}_{2}$ & - & 600 & ad 5 & 180 \\
$\mathrm{P}_{3}$ & 2,0 & 600 & ad 5 & \\
$\mathrm{B}_{3}$ & - & 600 & ad 5 & 40 \\
$\mathrm{P}_{4}$ & 2,0 & 600 & ad 5 & \\
$\mathrm{B}_{4}$ & - & 600 & ad 5 & 300 \\
$\mathrm{P}_{5}$ & 2,0 & 600 & ad 5 & \\
$\mathrm{B}_{5}$ & - & 600 & & \\
\hline
\end{tabular}

Keterangan : P : tabung perlakuan, masing-masing kelompok dibuat tiga; B : tabung blangko, masing- masing kelompok dibuat satu.

Selanjutnya nilai transmisi eritema sediaan tabir surya dapat dihitung dengan cara mengalikan transmisi (T) dengan faktor efektivitas eritema (Fe). Nilai transmisi pigmentasi dihitung dengan cara mengalikan nilai transmisi (T) dengan faktor efektivitas pigmentasi (Fp).

$$
\begin{aligned}
& \text { \%Transmisi Eritema } \\
& =\frac{\sum \boldsymbol{T} \times \boldsymbol{F e}}{\sum F e} \quad \% \text { Transmisi Pigmentasi }=\frac{\sum \boldsymbol{T} \times \boldsymbol{F p}}{\sum F p}
\end{aligned}
$$

Uji Aktivitas Fotodegradasi Tirosin

Pembuatan kurva baku tirosin diawali dengan membuat berbagai seri kadar larutan tirosin dari larutan induk tirosin $0,05 \%$ meliputi konsentrasi 0,$075 ; 0,100 ; 0,125 ; 0,150 ; 0,175$; 0,$200 ; 0,225 ; 0,250 ; 0,275 \mathrm{mg} / \mathrm{ml}$, lalu dilakukan pengukuran absorbansi tirosin menggunakan metode Millon. Pengaruh lama penyinaran terhadap fotodegradasi oleh tirosin dan rhetoflam dilakukan dalam tabun. Detail penambahan serta lamanya penyinaran terdapat pada Tabel III.

Kemudian, masing-masing kelompok (beserta blangko) dimasukkan ke dalam kotak penyinaran yang berukuran 73,5 x 48 x 26,5 cm dan dilakukan penyinaran. Sebuah lampu UV C 20 watt diletakkan di dalam kotak dengan jarak antara tabung dengan lampu $10 \mathrm{~cm}$. Lalu tirosin sisa ditetapkan absorbansinya. Komposisi bahan dalam tabung perlakuan untuk uji pengaruh ekstrak dan vitamin $\mathrm{C}$ terhadap fotodegradasi tirosin ada pada Tabel IV.

Metode Millon dipilih untuk mengukur tirosin sisa. Sebanyak 1 ml larutan uji yang telah disinari diambil dan dimasukkan dalam tabung reaksi. Kemudian, sebanyak $1 \mathrm{ml}$ larutan $\mathrm{NaOH}$ 1,2 ditambahkan dan diinkubasi dalam waterbath selama 1 jam dengan suhu $60^{\circ} \mathrm{C}$. Setelah 1 jam, ditambahkan 1,5 ml HgSO 4 $15 \%$ 
Tabel IV. Komposisi Bahan dalam Tiap Tabung Perlakuan pada Uji Pengaruh Ekstrak dan Vitamin C terhadap Fotodegradasi Tirosin

\begin{tabular}{|c|c|c|c|c|c|}
\hline \multirow{2}{*}{$\begin{array}{l}\text { Kelompok } \\
\text { Perlakuan }\end{array}$} & \multicolumn{5}{|c|}{ Isi Bahan dalam Tabung } \\
\hline & $\begin{array}{c}\text { Tirosin } \\
0,05 \%(\mathrm{ml})\end{array}$ & $\begin{array}{c}\text { Rhetoflam } \\
1 \%(\mu l)\end{array}$ & $\begin{array}{c}\text { Ekstrak Etanol Temu } \\
\text { Kunci } 0,15 \%(\mu l)\end{array}$ & $\begin{array}{c}\text { Vitamin C } \\
0,15 \%(\mu l)\end{array}$ & $\begin{array}{l}\text { Aquadest } \\
\text { (ml) }\end{array}$ \\
\hline $\mathrm{P}_{0}$ & 2,0 & - & - & - & ad 5 \\
\hline $\mathrm{B}_{0}$ & - & - & - & - & ad 5 \\
\hline $\mathrm{P}_{1}$ & 2,0 & 600 & - & - & ad 5 \\
\hline $\mathrm{B}_{1}$ & - & 600 & - & - & ad 5 \\
\hline $\mathrm{P}_{2}$ & 2,0 & 600 & - & - & ad 5 \\
\hline $\mathrm{B}_{2}$ & - & 600 & - & - & ad 5 \\
\hline $\mathrm{P}_{3}$ & 2,0 & 600 & - & - & ad 5 \\
\hline $\mathrm{B}_{3}$ & - & 600 & - & - & ad 5 \\
\hline $\mathrm{P}_{4}$ & 2,0 & 600 & 100 & - & ad 5 \\
\hline $\mathrm{B}_{4}$ & - & 600 & 100 & - & ad 5 \\
\hline $\mathrm{P}_{5}$ & 2,0 & 600 & - & 100 & ad 5 \\
\hline $\mathrm{B}_{5}$ & - & 600 & - & 100 & ad 5 \\
\hline
\end{tabular}

Keterangan: P : tabung perlakuan masing-masing kelompok dibuat enam; B : tabung blangko masing-masing kelompok dibuat satu.

dalam $\mathrm{H}_{2} \mathrm{SO}_{4} \quad 5 \mathrm{~N}$ dan $1 \mathrm{ml} \mathrm{NaNO}_{2} \quad 0,2 \%$, kemudian divortex. Absorbansi larutan diukur setelah 23 menit dengan spektrofotometer pada operating time dan panjang gelombang maksimum.

\section{Analisis Data}

Data hasil analisis spektrofotometri berupa persen transmisi eritema dan persen transmisi pigmentasi sediaan tabir surya. Data tersebut menunjukkan pengaruh penambahan ekstrak etanol rimpang temu kunci ke dalam sediaan tabir surya. Uji Kruskal-Whitney dipilih untuk mengetahui persen transmisi eritema dan pigmentasi secara non-parametik, dilanjutkan dengan uji Mann-Whitney untuk mengetahui perbedaan nilai persen transmisi eritema dan persen transmisi pigmentasi tiap formula. Kadar fenolik total ekivalen asam galat (EAG) diukur menggunakan metode Folin-Ciocalteu dan aktivitas penghambatan fotodegradasi tirosin dibandingkan dengan vitamin $\mathrm{C}$ pada kadar yang sama yaitu $0,15 \%$.

\section{HASIL DAN PEMBAHASAN \\ Hasil Proses Ekstraksi}

Sebanyak 500 gram simplisia serbuk rimpang temu kunci diperoleh ekstrak kental sebanyak 60,33 gram. Proses ekstraksi dari simplisia rimpang temu kunci diperoleh ekstrak kental sebanyak 60,33 gram, diperoleh rendemen $12,07 \%$.

\section{Kadar Fenolik Total}

Kurva baku asam galat dibuat dengan seri kadar (9 kadar, 0,1005 s/d 0,9045 mg/100 $\mathrm{ml}$ ) terhadap absorbansi pada panjang gelombang $750 \mathrm{~nm}$. Dari pengukuran diperoleh persamaan regresi $\mathrm{y}=1,146 \mathrm{x}-0,037(\mathrm{x}=\mathrm{kadar}$ asam galat dalam $\mathrm{mg} / 100 \mathrm{ml}$ dan $\mathrm{y}=$ Absorbansi) dengan nilai koefisien korelasi 0,99 (rhitung) yang lebih besar dari $\mathrm{r}$ table untuk $\mathrm{n}=$ 9; $\mathrm{P}=0,95$ sebesar 0,666 , sehingga persamaan kurva baku tersebut dapat digunakan pada penelitian ini untuk menghitung kadar fenolik total dalam ekstrak rimpang temu kunci. Kurva baku ini disajikan pada Gambar 1.

Kandungan senyawa fenolik total diekspresikan dengan \% b/b ekivalen asam galat (EAG) karena beum diketahui struktur kimianya dalam ekstrak. Hasil kandungan senyawa fenolik total dari ekstrak buah mahkota dewa disajikan dalam Tabel V.

\section{Uji Pendahuluan Formulasi Uji Mutu Fisik}

Berdasarkan hasil uji mutu fisik yang tersaji pada Tabel VI, dari keempat formula menunjukkan karakteristik fisik hamper sama dari warna (coklat muda), bau (khas rimpang temu kunci), tekstur (halus, lembut, tidak lengket, dan mudah dicuci), homogen, $\mathrm{pH} 5$, 


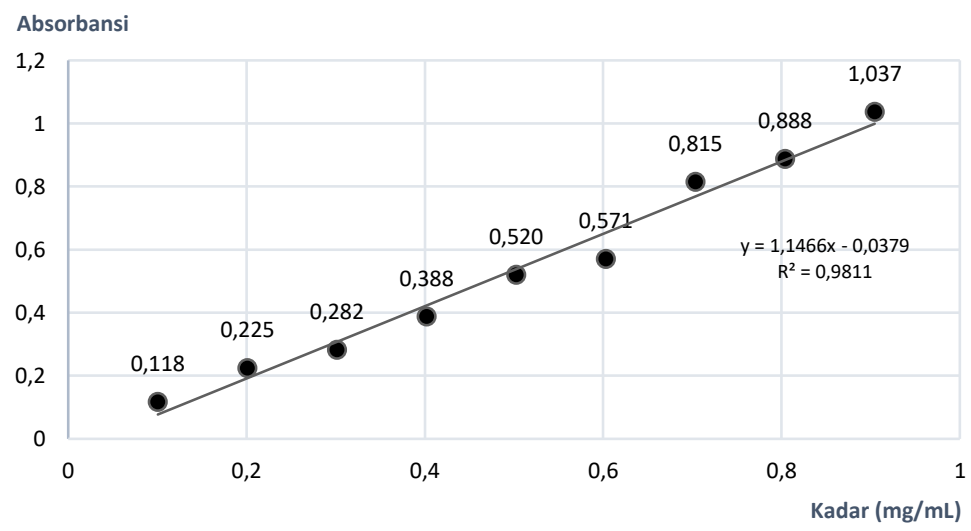

Gambar 1. Kurva Baku Asam Galat

Tabel V. Kadar Fenolik Total Ekstrak yang Dihitung sebagai \% b/b EAG

\begin{tabular}{cccc}
\hline Replikasi & Absorbansi Temu Kunci & Kadar (\% b/b EAG) \\
\hline $\mathbf{1}$ & & 0,570 & 7,05 \\
$\mathbf{2}$ & & 0,591 & 7,29 \\
$\mathbf{3}$ & & 0,580 & 7,17 \\
$\mathbf{4}$ & & 0,559 & 6,92 \\
$\mathbf{5}$ & & 0,566 & 7,00 \\
$\mathbf{6}$ & & 0,583 & 7,20 \\
& $\bar{X}$ & & 7,11 \\
& $\bar{X} \pm \mathrm{LE}$ & & 7,11 目 0,15 \\
& $\mathrm{CV}(\%)$ & & 1,9 \\
\hline
\end{tabular}

akan tetapi viskositas dari keempat formula agak berbeda dimana viskositas tertinggi dimiliki oleh formula 3 dengan harga viskositas sebesar 78 poise dan viskositas terendah dimiliki oleh formula 4 dengan nilai harga viskositas sebesar 43 poise. Dari keempat formula sebenarnya memenuhi syarat baik untuk krim yaitu warna, bau, dan teksturnya menyenangkan, homogen, namun viskositas masing-masing formula berbeda, dalam hal ini viskositas dari formula 4 terlalu kecil.

Sediaan krim berwarna coklat muda karena adanya ekstrak etanol rimpang temu kunci yang berwarna coklat dan berbau khas temu kunci karena adanya kandungan minyak atsiri dalam rimpang temu kunci.

Perbedaan viskositas terjadi karena adanya perbedaan konsentrasi komponen emulgator yaitu span 60 dan tween 60. Formula 1 dengan komponen emulgator $2 \%$ span 60 dan 1,5\% tween 60 menghasilkan viskositas sebesar 62 poise, formula 2 yang terdiri dari $1,5 \%$ span 60 dan 2\% tween 60 menghasilkan krim dengan viskositas 72 poise, formula 3 dengan hanya terdiri dari 3,5\% span 60 menghasilkan sediaan krim dengan viskositas 78 poise, dan formula 4 hanya terdiri dari 3,5\% tween 60 menghasilkan krim dengan viskositas 43 poise.

\section{Uji Daya Sebar}

Daya sebar dimana tersaji dalam Tabel VII, menunjukkan hasil bahwa keempat formula mempunyai daya sebar hampir sama kecuali formula 4 dimana mempunyai daya sebar sangat besar yaitu dengan diameter penyebaran 6,3 pada pemberian beban 57 gram dan 7,45 pada pemberian beban 407 gram. Pada formula 3 pemberian beban awal 57 gram krim mampu menyebar dengan diameter 4,55 dan pada penambahan beban 407 gram krim mampu menyebar dengan diameter 5,65.

Hasil daya sebar pada formula 1 dan formula 2 mempunyai diameter penyebaran hampir sama dengan formula 3 yaitu $5,48 \mathrm{~cm}$ untuk formula 1 dan $5,15 \mathrm{~cm}$ untuk formula 2 pada pemberian beban 57 gram dan pada pemberian beban 407 gram memberikan diameter penyebaran $5,98 \mathrm{~cm}$ untuk formula 1 dan $5,72 \mathrm{~cm}$ untuk formula 2. 
Tabel VI. Hasil Uji Mutu Fisik Pendahuluan

\begin{tabular}{lcccc}
\hline Karakter Sediaan & Formula 1 & Formula 2 & Formula3 & Formula 4 \\
\hline Warna & Coklat muda & Coklat muda & Coklat muda & Coklat muda \\
Kau & Khas rimpang & Khas rimpang & Khas rimpang & Khas rimpang \\
& temu kunci & temu kunci & temu kunci & temu kunci \\
& Halus,lembut, & Halus,lembut, & Halus,lembut, & Halus,lembut, \\
Tekstur & mudah dicuci, & mudah dicuci, & mudah dicuci, & mudah dicuci, \\
& tidak lengket & tidak lengket & tidak lengket & tidak lengket \\
Homogenitas & Homogen & Homogen & Homogen & Homogen \\
pH & 5 & 5 & 5 & 5 \\
Viskositas & 62 Poise & 72 Poise & 78 Poise & 43 Poise \\
\hline
\end{tabular}

Tabel VII. Hasil Uji Daya Sebar

\begin{tabular}{ccccc}
\hline Beban (gram) & F1 (cm) & F2 (cm) & F3 (cm) & F4 (cm) \\
\hline 57 & 5,48 & 5,15 & 4,55 & 6,3 \\
107 & 5,6 & 5,42 & 4,73 & 6,5 \\
157 & 5,62 & 5,58 & 4,83 & 6,65 \\
207 & 5,62 & 5,6 & 5,07 & 6,85 \\
257 & 5,7 & 5,62 & 5,12 & 7 \\
307 & 5,72 & 5,63 & 5,28 & 7,13 \\
357 & 5,8 & 5,7 & 5,45 & 7,25 \\
407 & 5,98 & 5,72 & 5,65 & 7,45 \\
\hline
\end{tabular}

Tabel VIII. Hasil Uji Daya Lekat

\begin{tabular}{ccccc}
\hline Replikasi & F1 (detik) & F2 (detik) & F3 (detik) & F4 (detik) \\
\hline I & 1,9 & 2,1 & 2 & 0,6 \\
II & 2,1 & 2,1 & 2,2 & 0,7 \\
III & 1,9 & 1,9 & 2 & 0,7 \\
rata-rata & 1,97 & 2,03 & 2,07 & 0,67 \\
\hline
\end{tabular}

Perbedaan hasil daya sebar dari masingmasing formula dikarenakan adanya perbedaan viskositas dari tiap formula. Viskositas merupakan suatu pernyataan tahanan terhadap cairan untuk dapat mengalir, semakin tinggi viskositas sediaan maka tahanannya semakin besar (Martin et al., 1993). Besarnya tahanan pada masa yang mempunyai sifat alir nonnewton atau pseudoplastik. Tetapi tidak berlaku untuk sifat alir Dilatan. Hal ini menyebabkan sediaan tersebut sulit untuk mengalir sehingga sediaan tersebut cenderung akan mempunyai daya sebar kecil. Data dapat ditunjukkan dengan hasil uji daya sebar dari formula 4 yang besar karena kecilnya viskositas pada formula 4 .

\section{Uji Daya Lekat}

Hasil uji daya lekat dimana tersaji pada Tabel VIII, menunjukkan bahwa pada formula 4 mempunyai daya lekat paling kecil daripada ketiga basis lain sehingga dengan kata lain basis formula 4 kurang sempurna melekat pada kulit dengan baik dan tidak tahan lama menempel pada kulit.

\section{Persen Pemisahan dengan Sentrifugasi}

Volume pemisahan dengan sentrifugasi dimana tersaji dalam Gambar 2, 3, dan 4 dapat dilihat bahwa formula 3 sangat tidak stabil karena dengan pemusingan berkecepatan 1000 rpm saja sudah terjadi pemisahan lebih dari $50 \%$. Pada formula 1, formula 2, dan formula 3 ketika diberi perlakuan pemusingan pada kecepatan $3000 \mathrm{rpm}$ pemisahan tidak terlalu besar. Sehingga dari hasil uji volume pemisahan dengan sentrifugasi ini dapat dikatakan bahwa formula 1, formula 2, dan formula 3 stabil terhadap pemusingan. 
Tatang Irianti, et al

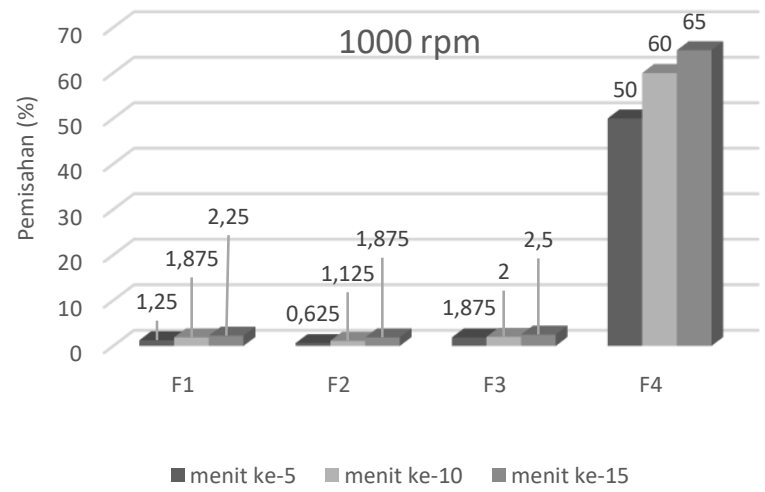

Gambar 2. Histogram Hasil Uji Pemisahan dengan Sentrifugasi 1000 rpm

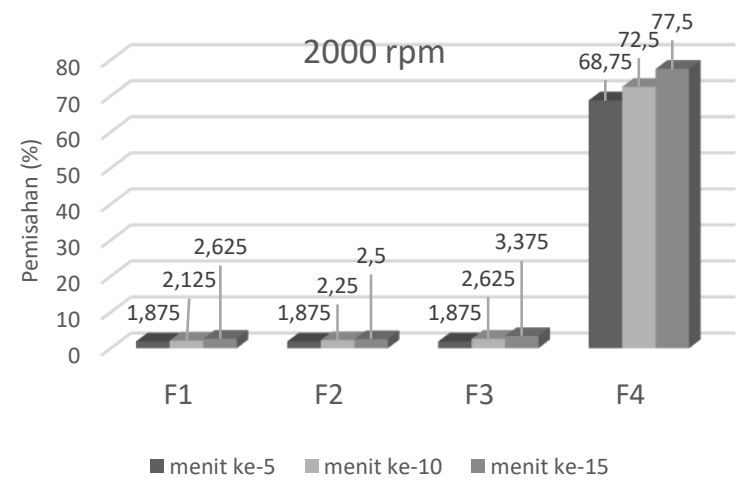

Gambar 3. Histogram Hasil Uji Pemisahan dengan Sentrifugasi 2000 rpm

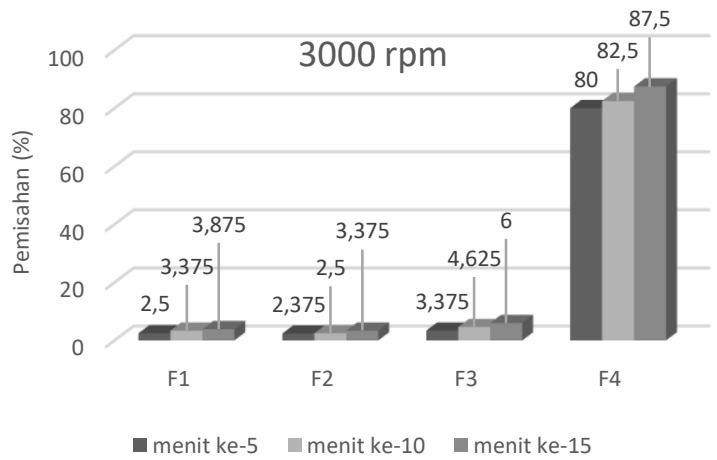

Gambar 4. Histogram Hasil Uji Pemisahan dengan Sentrifugasi 3000 rpm

\section{Uji Persen Pemisahan dengan Sedimentasi Suhu $50^{\circ} \mathrm{C}$}

Berdasarkan hasil uji volume pemisahan akibat sedimentasi pada Gambar 5 menunjukkan bahwa formula 2 merupakan volume yang terstabil karena pada formula 2 tidak terjadi pemisahan sampai menit ke-30. Sedangkan pada formula lain telah terjadi pemisahan terlebih dahulu yaitu formula 1 terjadi pemisahan pada menit ke-30, formula 3 pada menit ke-30, dan formula empat terjadi pemisahan pada menit ke-20.

\section{Suhu Ruang}

Hasil uji volume pemisahan akibat sedimentasi pada suhu ruang yang terlihat pada 


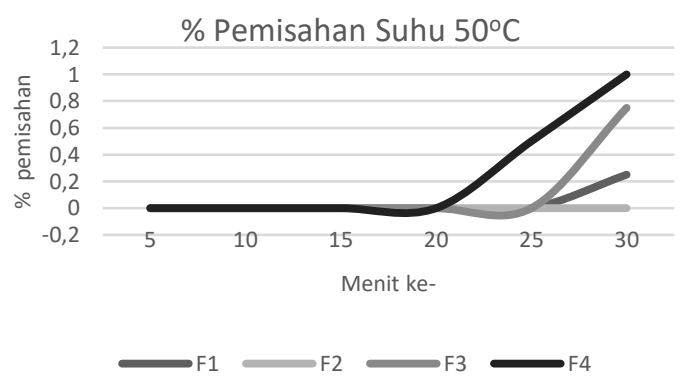

Gambar 5. Grafik Hasil Uji Pemisahan dengan Suhu $50^{\circ} \mathrm{C}$

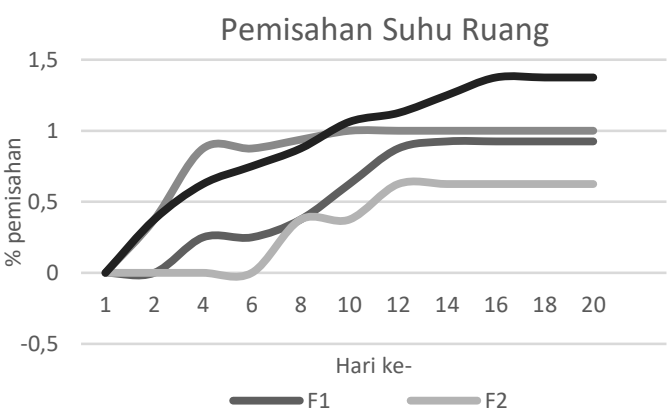

Gambar 5. Grafik Hasil Uji Pemisahan dengan Suhu Ruang

Tabel IX. Formula Sediaan Tabir Surya

\begin{tabular}{cccc}
\hline Formula & Basis & Oksibenson & Ekstrak \\
\hline Formula 1 & + & - & - \\
Formula 2 & + & $6 \%$ & - \\
Formula 3 & + & - & $4 \%$ \\
Formula 4 & + & - & $6 \%$ \\
Formula 5 & + & - & $8 \%$ \\
Formula 6 & + & $6 \%$ & $4 \%$ \\
Formula 7 & + & $6 \%$ & $6 \%$ \\
Formula 8 & + & $6 \%$ & $8 \%$ \\
\hline
\end{tabular}

Gambar 6, menunjukkan bahwa pemisahan yang terkecil dimiliki oleh formula 2 dan volume pemisahan terbesar pada formula 4 .

Dari hasil uji-uji yang dilakukan terhadap keempat formula basis, dapat disimpulkan bahwa formula 2 dengan komposisi emulgator 1,5\% span 60 dan 2\% tween 60 merupakan formula paling baik daripada formula lainnya karena berdasarkan hasil uji-uji menunjukkan bahwa komposisi emulgator pada formula 2 lebih menstabilkan krim daripada komposisi emulgator lainnya.

\section{Formulasi Sediaan Tabir Surya Penentuan Formula Sediaan}

Hasil formula basis paling baik pada orientasi adalah formula 2 dengan komposisi emulgator 2\%, tween 0 dan 1,5\% span 60 . Selanjutnya, sediaan krim tabir surya untuk pengujian nilai \% transmisi eritema dan pigmentasi sesuai dengan basis formula 2. Pada tabel IX dapat dilihat fformula baru dibuat dengan penambahan bahan aktif oksibenson dan ekstrak etanol rimpang temu kunci yang mempunyai komposisi berbeda ( 8 formula).

Oleh karena itu, pembuatan sediaan krim tabir surya untuk diuji nilai \% transmisi eritema dan pigmentasi digunakan komposisi basis terpilih yaitu basis formula 2 dengan penambahan bahan aktif oksibenson dan ekstrak etanol rimpang temu kunci yang dibuat dalam 8 formula baru. Komposisi masingmasing formula dapat dilihat pada Tabel IX.

\section{Hasil Uji Mutu Fisik Sediaan}

Berdasarkan hasil uji mutu fisik formula sediaan tabir surya dimana tersaji dalam Tabel X dan Gambar 7, didapatkan hasil bentuk krim, berwarna putih untuk sediaan tanpa oksibenson dan ekstrak rimpang temu kunci, berwarna putih agak kuning untuk sediaan dengan oksibenson tanpa ekstrak rimpang temu kunci, dan coklat muda untuk sediaan berisi ekstrak rimpang temu kunci dengan dan tanpa oksibenson. Sediaan yang mengandung ekstrak rimpang temu kunci mempunyai bau khas dari rimpang temu kunci dan sediaan tanpa ekstrak rimpang temu kunci tidak berbau, homogenitasnya untuk semua formula sediaan yaitu semua formula homogen, tekstur untuk semua sediaan sama yaitu halus dan lembut. Viskositas yang dihasilkan berkisar antara 65 sampai 70 poise dan memiliki pH 5 untuk semua formula sediaan tabir surya. 


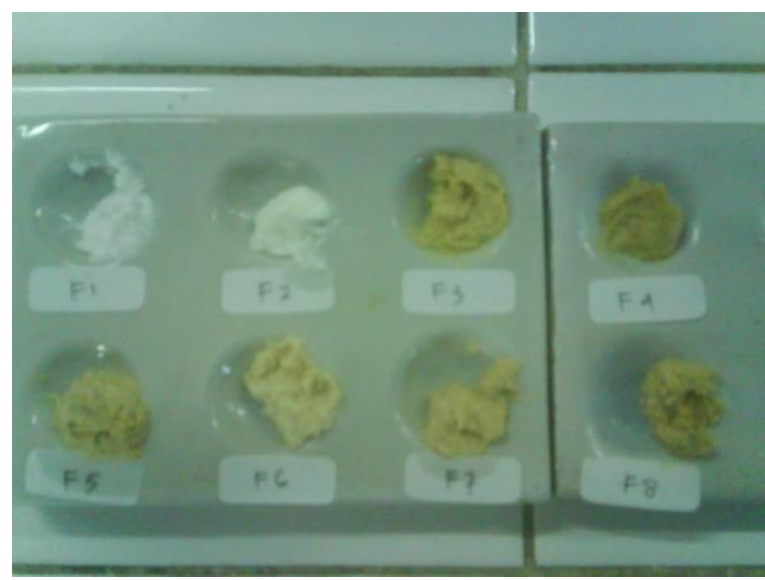

Gambar 7. Sediaan Krim Tabir Surya

Tabel X. Hasil Uji Mutu Fisik Sediaan Tabir Surya

\begin{tabular}{|c|c|c|c|c|c|c|c|c|}
\hline $\begin{array}{c}\text { Karakter } \\
\text { fisika }\end{array}$ & F 1 & F 2 & F 3 & F 4 & F 5 & F 6 & F 7 & F 8 \\
\hline \multicolumn{9}{|l|}{ Organoleptis: } \\
\hline $\begin{array}{l}\text { Bentuk } \\
\text { Warna }\end{array}$ & $\begin{array}{l}\text { krim } \\
\text { putih }\end{array}$ & $\begin{array}{l}\text { krim } \\
\text { putih } \\
\text { agak } \\
\text { kuning }\end{array}$ & $\begin{array}{l}\text { krim } \\
\text { coklat } \\
\text { muda }\end{array}$ & $\begin{array}{c}\text { Krim } \\
\text { coklat mud } \\
\text { a }\end{array}$ & $\begin{array}{l}\text { krim } \\
\text { coklat } \\
\text { muda }\end{array}$ & $\begin{array}{l}\text { Krim } \\
\text { coklat } \\
\text { muda }\end{array}$ & $\begin{array}{l}\text { krim } \\
\text { coklat } \\
\text { muda }\end{array}$ & $\begin{array}{l}\text { Krim } \\
\text { coklat } \\
\text { muda }\end{array}$ \\
\hline Bau & $\begin{array}{c}\text { tidak } \\
\text { berbau }\end{array}$ & $\begin{array}{c}\text { tidak } \\
\text { berbau }\end{array}$ & $\begin{array}{l}\text { Bau } \\
\text { khas } \\
\text { temu } \\
\text { kunci }\end{array}$ & $\begin{array}{c}\text { Bau } \\
\text { khas temu } \\
\text { kunci }\end{array}$ & $\begin{array}{c}\text { Bau khas } \\
\text { temu } \\
\text { kunci }\end{array}$ & $\begin{array}{c}\text { Bau khas } \\
\text { temu } \\
\text { kunci }\end{array}$ & $\begin{array}{c}\text { Bau khas } \\
\text { temu } \\
\text { kunci }\end{array}$ & $\begin{array}{c}\text { Bau khas } \\
\text { temu } \\
\text { kunci }\end{array}$ \\
\hline Homogen & уа & уа & уа & Ya & уа & Ya & уа & уа \\
\hline Tekstur & $\begin{array}{l}\text { halus, } \\
\text { lembut }\end{array}$ & $\begin{array}{l}\text { halus, } \\
\text { lembut }\end{array}$ & $\begin{array}{l}\text { halus, } \\
\text { lembut }\end{array}$ & $\begin{array}{l}\text { halus, } \\
\text { lembut }\end{array}$ & $\begin{array}{l}\text { halus, } \\
\text { lembut }\end{array}$ & $\begin{array}{l}\text { halus, } \\
\text { lembut }\end{array}$ & $\begin{array}{l}\text { halus, } \\
\text { lembut }\end{array}$ & $\begin{array}{l}\text { halus, } \\
\text { lembut }\end{array}$ \\
\hline pH & 5 & 5 & 5 & 5 & 5 & 5 & 5 & 5 \\
\hline Viskositas & 65 & 70 & 65 & 65 & 68 & 70 & 65 & 68 \\
\hline
\end{tabular}

\section{Analisis secara Spektrofotometri Hasil Perhitungan \%Transmisi Eritema (\%Te)}

Nilai persen transmisi eritema pada Tabel XI menunjukkan hasil bahwa formula yang hanya terdiri dari basis saja yaitu pada formula 1 mempunyai nilai persen transmisi eritema 98,73. Pada penambahan ekstrak etanol rimpang temu kunci berbagai konsentrasi (formula 3, 4, dan 5) mampu menurunkan nilai transmisi eritema 0,72-0,76 kali terhadap penurunan nilai transmisi eritema sediaan tabir surya dimana hanya mengandung bahan aktif oksibenson (formula 2), penambahan oksibenson mampu menurunkan nilai transmisi eritema hingga mencapai 0,08 .

Penambahan ekstrak etanol rimpang temu kunci $6 \%$ dengan oksibenson $6 \%$ mampu menurunkan nilai persen transmisi eritema 1,00 kali lebih baik daripada sediaan tabir surya hanya terdiri dari oksibenson saja.

Dari hasil analisa statistik dengan Kruskal Walis diketahui bahwa terdapat perbedaan antar formula dan dari hasil analisis dengan Mann Whitney diperoleh hasil bahwa terjadi perbedaan bermakna antara formula 6 , formula 7, dan formula 8 terhadap formula 1 , begitu juga formula 6 dan formula 7 menunjukkan perbedaan bermakna terhadap formula 2 .

\section{Hasil Perhitungan \%Transmisi Pigmentasi (\%Tp)}

Pada sediaan tabir surya yang hanya terdiri dari basis saja mempunyai nilai transmisi pigmentasi sebesar 49,48 (Tabel XII). 


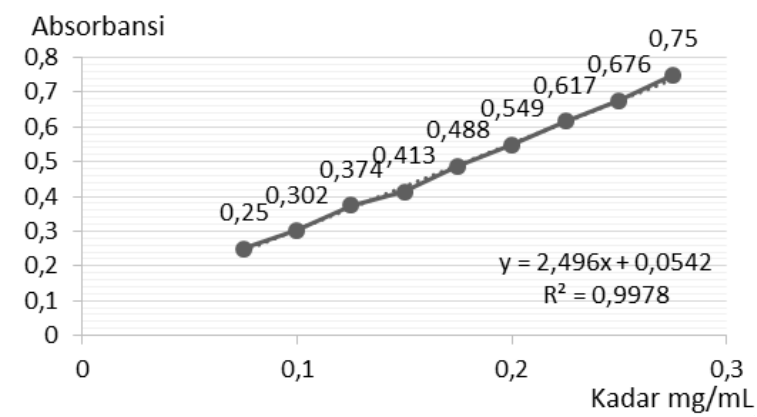

Gambar 9. Kurva Baku Tirosin

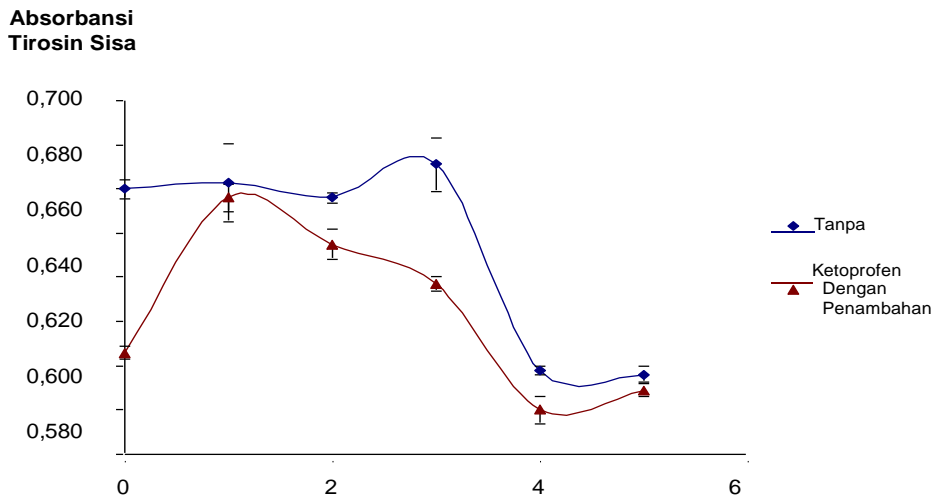

Gambar 10. Kurva Hubungan Penyinaran Lampu UV terhadap Absorbansi Tirosin Sisa

Tabel XI. Hasil Uji \% Transmisi Eritema

\begin{tabular}{ccccc}
\hline \multirow{2}{*}{ Formula } & \multirow{2}{*}{ Nilai \% Te } & \multicolumn{3}{c}{ Komposisi bahan } \\
\cline { 2 - 5 } & 98.73 & Bahan & Oksibenson & Ekstrak \\
\hline 1 & 0.08 & + & - & - \\
2 & 27.97 & + & $6 \%$ & - \\
3 & 24.15 & + & - & $4 \%$ \\
4 & 26.89 & + & - & $6 \%$ \\
5 & 0.22 & + & - & $8 \%$ \\
6 & 0.01 & + & $6 \%$ & $4 \%$ \\
7 & 0.15 & + & $6 \%$ & $6 \%$ \\
8 & & + & $6 \%$ & $8 \%$ \\
\hline
\end{tabular}

Tabel XII. Hasil Uji \% Transmisi Pigmentasi

\begin{tabular}{ccccc}
\hline \multirow{2}{*}{ Formula } & Nilai \% Tp & \multicolumn{3}{c}{ Komposisi bahan } \\
\cline { 3 - 5 } & 49,48 & Basis & Oksibenson & Ekstrak \\
\hline 1 & 2,68 & + & - & - \\
2 & 22,98 & + & $6 \%$ & - \\
3 & 20,93 & + & - & $4 \%$ \\
4 & 21,63 & + & - & $6 \%$ \\
5 & 3,63 & + & - & $8 \%$ \\
6 & 1,61 & + & $6 \%$ & $4 \%$ \\
7 & 3,35 & + & $6 \%$ & $6 \%$ \\
8 & & + & $6 \%$ & $8 \%$ \\
\hline
\end{tabular}


Tabel XIII. Absorbansi tirosin sisa pada masing-masing kelompok perlakuan setelah penyinaran 4 jam diukur pada $\lambda 492 \mathrm{~nm}$

\begin{tabular}{ccccc}
\hline \multirow{2}{*}{ Replikasi } & \multicolumn{4}{c}{ Absorbansi perlakuan } \\
\cline { 2 - 4 } & P1 & P2 & P3 & P4 \\
\hline 1 & 0,586 & 0,540 & 0,606 & 0,573 \\
2 & 0,580 & 0,545 & 0,591 & 0,565 \\
3 & 0,586 & 0,544 & 0,614 & 0,575 \\
4 & 0,581 & 0,543 & 0,617 & 0,585 \\
5 & 0,579 & 0,537 & 0,615 & 0,575 \\
6 & 0,578 & 0,536 & 0,611 & 0,568 \\
Rerata & 0,582 & 0,541 & 0,609 & 0,574 \\
Standar Deviasi & 0,004 & 0,004 & 0,010 & 0,007 \\
Standar Deviasi Relatif (\%) & 0,602 & 0,696 & 1,58 & 1,207 \\
\hline
\end{tabular}

Keterangan : P1: Tirosin; P2: Tirosin dengan penambahan ketoprofen P3: Tirosin dengan penambahan ketoprofen dan ekstrak etanol rimpang temu kunci, P4: Tirosin dengan penambahan ketoprofen dan vitamin C

Penurunan nilai persen transmisi pigmentasi dengan penambahan ekstrak etanol rimpang temu kunci berbagai konsentrasi (formula 3, 4, dan 5) sebesar 0,57-0,61 kali terhadap penurunan nilai transmisi pigmentasi pada sediaan tabir surya dimana hanya mengandung bahan aktif oksibenson (formula 2). Penurunan nilai transmisi pigmentasi ini lebih besar daripada sediaan tabir surya mengandung oksibenson, sehingga dapat dikatakan bahwa penambahan ekstrak etanol rimpang temu kunci $6 \%$ dan oksibenson $6 \%$ 1,02 kali lebih baik daripada sediaan tabir surya hanya terdiri dari oksibenson saja.

Dari hasil analisa statistik dengan Kruskal Walis diketahui bahwa terdapat perbedaan bermakna antar formula dan dari hasil analisis Mann Whitney diperoleh hasil bahwa formula 6 , formula 7 , dan formula 8 terjadi perbedaan bermakna terhadap formula 1 maupun formula 2 .

\section{Pengaruh Lama Penyinaran Fotodegradasi Tirosin}

Sembilan kadar tirosin terhadap absorbansinya dibuat kurva baku dan dihitung linearitasnya (Gambar 9). Persamaannya adalah $\mathrm{y}=2,496 \mathrm{x}+0,0542$ dengan nilai koefisien korelasinya ( $\mathrm{r}$ hitung $=0,9978$ ). Pengaruh lama penyinaran $(0,60,120,180,240$ dan 300 menit) Terhadap fotodegradasi tirosin menunjukkan bahwa nilai absorbansi terkecil ditunjukkan pada pejanan lampu UV selama 4 jam (Gambar 10). Karena nilai absorban berbanding lurus dengan kadar tirosin sisa maka ini berarti fotodegradasi tirosin optimal pada penyinaran selama 4 jam. Dengan demikian pejanan selama 4 jam dijadikan dasar pemejanan lampu UV selanjutnya dalam penelitian ini.

\section{Aktivitas Inhibisi Fotodegradasi Tirosin Ekstrak Rimpang Temu Kunci}

Hasil pengukuran absorbansi tirosin pada berbagai kelompok perlakuan pada Tabel XIII dan hasil analisis statistik menunjukkan bahwa ekstrak etanol rimpang temu kunci mampu menghambat secara signifikan fotodegradasi tirosin yang diinduksi ketoprofen. Aktivitas inhibisi ekstrak dibandingkan dengan vitamin C memiliki nilai sebesar 2,06.

Aktivitas inhibisi ekstrak dibandingkan dengan vitamin C:

Ekstrak Etanol Rimpang Temu Kunci

$$
=\frac{P 3-P 2}{P 6-P 2}=\frac{0,609-0,541}{0,574-0,541}=\frac{0,068}{0,033}=2,06
$$

Ekstrak air dari rimpang temu kunci menunjukkan adanya aktivitas inhibisi fotodegradasi tirosin dalam kaitannya dengan aktivitas fotoproteksi. Ekstrak tersebut mampu menghambat fotodegradasi tirosin terhadap sinar UV pada nilai inhibisi sebesar 2,06.

Dengan demikian, ekstrak etanol rimpang temu kunci menunjukkan adanya 
aktivitas inhibisi fotodegradasi tirosin dalam kaitannya dengan aktivitas fotoproteksi. Ekstrak etanol rimpang temu kunci mampu menghambat fotodegradasi tirosin terhadap sinar UV pada nilai inhibisi sebesar 2,06.

\section{KESIMPULAN}

Berdasarkan hasil penelitian yang telah dilakukan, penambahan ekstrak etanol rimpang temu kunci pada sediaan tabir surya (formula 3, 4, dan 5) dapat meningkatkan efektifitas sediaan tabir surya ditunjukkan dengan penurunan transmisi eritema 0,72-0,76 kali, dan penurunan transmisi pigmentasi 0,57-0,61 kali terhadap penurunan sediaan tabir surya mengandung bahan aktif oksibenson (formula 2). Pemberian ekstrak etanol rimpang temu kunci 6\% mampu meningkatkan efektifitas sediaan tabir surya mengandung oksibenson $6 \%$ (formula 7) ditunjukkan dengan penurunan transmisi eritema 1,00 kali dan penurunan transmisi pigmentasi 1,02 kali lebih baik dari sediaan tabir surya mengandung bahan aktif oksibenson saja (formula 2). Sedangkan kandungan fenolik total ekstrak etanol rimpang temu kunci adalah sebesar 7,11 $\pm 0,15$ \% EAG dengan aktivitas penghambatan fotodegradasi tirosin 2,06 kali lebih besar dibandingkan dengan vitamin $\mathrm{C}$ pada kadar sama, yaitu $0,15 \%$. Sedangkan kandungan fenolik total ekstrak etanol rimpang temu kunci adalah sebesar 7,11 $\pm 0,15 \%$ EAG dengan aktivitas penghambatan fotodegradasi tirosin 2,06 kali lebih besar dibandingkan dengan vitamin C pada kadar sama, yaitu 0,15\%. Degradasi tirosin yang berfungsi sebagai prekursor terbentuknya melanin dapat diminimalkan, sehingga optimal peran melanin sebagai penginduksi energi foton cahaya menjadi molekul baru. Hal ini menunjukkan bahwa ekstrak etanol rimpang temu kunci mampu digunakan sebagai bahan tambahan dalam sediaan tabir surya untuk meningkatkan mutu proteksi terhadap sinar matahari.

\section{UCAPAN TERIMA KASIH}

Kami mengucapkan terimakasih kepada Frau Prof.Dr. Ulrike Holzgrabe dan Deutscher Akademischer AustauschDienst (DAAD) Jerman yang telah mendanai dan memberi fasilitas beberapa instrumen. Selanjutnya juga diucapkan terimakasih kepada Dekan Fakultas Farmasi dan Ibu Kepala Departemen Kimia Farmasi, UGM atas bantuan serta kemudahan yang diberikan pada penelitian kami.

\section{DAFTAR PUSTAKA}

Backer, A and Van Den Brink, B. (1965). Flora of Java (Spermatophytes Only) (Volume I,). The Nederlands: Noordhoff-Groningen.

Barel, A. O. dkk. (2001). Handbook of Cosmetic Science and Technology. New York: Marcel Dekker, Inc.

Cumpelik, B. M. (1972). Analytical

Prosedures and Evaluation of Sunscreen. , J.Soc. Cos. Chem.

Dröge W. (2002). Free Radicals in the Physiological Control of Cell Function. Physiological Rev. Jan: 47-95.

Halliwel, B. dan Gutteridge, J. M. C. (1999). Free Radical in Biology and Medicine. New York: Oxford Unyversity Press.

Kockler, J., Oelgemöller, M., Robertson, S., \&

Glass, B. D. (2012). Journal of Photochemistry and Photobiology C: Photochemistry Reviews Photostability of sunscreens. "Journal of Photochemistry \& Photobiology, C: Photochemistry Reviews," 13(1), 91-110.

Martin A, Swarbrick, C. A. (1993). Farmasi Fisik 2. (U. Press, Ed.) (Edisi Keti). Jakarta (ID).

Raga, Y. . (2012). Respons Pertumbuhan Dan Hasil Bawang Sabrang (Eleutherine americana Merr) Pada Beberapa Jarak Tanam Dan Berbagai Tingkat Pemotongan Umbi Bibit. Jurnal Online Agroekoteknologi Vol. 1, No. 1, Desember 2012, 1(1), 159-171.

Sartini dan Gemini, A. (n.d.). 2008. Ekstraksi Komponen Bioaktif Dari Limbah Kulit Buah Kakao Dan Pengaruhnya terhadap Aktivitas Antioksidan Dan Antimikroba. Jurnal Fakultas Farmasi Unhas, hal 1-6.

Shaath NA. (1990). The Chemistry of Sunscreens. New York: Marcel Dekker, Inc.

Shindo, K., Kato, M., Kinoshita, A., Kobayashi, A., Koike, Y. (n.d.). Analysis of Antioxidant Activities

Contained in the Boesenbergia pandurata Schult Rhizome. Biosci Biotechnol Biochem, 70(9), 2281-4.

Suryanto, E. (2012). Fitokimia Antioksidan. 
Surabaya: Putra Media Nusantara.

Svobodova, A., J. Psotova., D. W. (2003). Natural Phenolics in the Prevention of UV-Induced Skin Damage. Biomed.

Tahir, I., Jumina, dan Y. I. (2002). Analisis aktivitas perlindungan sinar uv secara,
Vol. 2(November), No. 3: 136.

Tewtrakul, S., \& Subhadhirasakul, S. (n.d.). HIV1 protease inhibitory substances from the rhizomes of Boesenbergia pandurata Holtt . Songklanakarin J. Sci. Technol, (April 2003), 25(4), 503-508. 